\title{
Optimizing the Antimicrobial Activity of Tasmanian Pepper Leaf Oil Emulsion as a Natural Preservative for Capsicum ${ }^{+}$
}

\author{
Maral Seidi Damyeh ${ }^{1, *}$, Ram Mereddy ${ }^{2}$, Michael E. Netzel ${ }^{1}$ and Yasmina Sultanbawa ${ }^{1}$ \\ 1 Queensland Alliance for Agriculture and Food Innovation (QAAFI), The University of Queensland, \\ Coopers Plains, QLD 4108, Australia; m.netzel@uq.edu.au (M.E.N.); y.sultanbawa@uq.edu.au (Y.S.) \\ 2 Department of Agriculture and Fisheries, Queensland Government, Coopers Plains, QLD 4108, Australia; \\ ram.mereddy@daf.qld.gov.au \\ * Correspondence: s.maral@uq.edu.au \\ + Presented at the third International Tropical Agriculture Conference (TROPAG 2019), Brisbane, Australia, \\ 11-13 November 2019.
}

Published: 1 February 2020

\begin{abstract}
The aim of this study was to produce and optimize Tasmanian pepper leaf (Tasmannia lanceolate; TPL) oil contained emulsion using sonication and Response Surface Methodology (RSM). Encapsulating hydrophobic bioactive components is influential in enhancing their applicability as well as their respected antimicrobial activity. The antimicrobial activity of investigated emulsions was evaluated through well diffusion assay against four different spoilage microorganisms isolated from fresh-cut capsicums. In order to optimize the preservative emulsion for further in vivo application, Box-Behnken design with three factors of TPL oil, Tween 80, and citric acid was used. According to the results, bacterial and fungal growth inhibition activity of the investigated emulsions was enhanced through increasing the concentration of citric acid and TPL oil, respectively. Optimization of the investigated variables was conducted after model fitting according to desirability function of Design Expert software. Our main goal was to obtain the maximum inhibitory effect against microbial growth. Therefore, the calculated optimum values were TPL at $1.08 \%$, Tween 80 at $0.15 \%$, and citric acid at $1.50 \%$, with the desirability of 0.978 . By and large, the susceptibility of yeast (i.e., Rhodotorula diobovata) against TPL contained emulsions showed to be the highest, which was followed by mold (i.e., Alternaria sp.), Gram-positive bacteria (i.e., Bacillus subtilis), and Gram-negative bacteria (i.e., Pseudomonas viridiflava), with predicted inhibition zones of 46.41, 33.03, 13.10, and $11.33 \mathrm{~mm}$. Optimized emulsion using Box-Behnken design is capable of inhibiting the growth of spoilage microorganisms in capsicum, and this understanding can help develop a natural-based preservative for fresh-cut capsicum.
\end{abstract}

Keywords: antimicrobial; emulsion; Tasmannia lanceolate; preservative

Author Contributions: M.S.D. conducted the experiments and wrote the manuscript. R.M., M.E.N. and Y.S. supervised the project, corrected, and revised the manuscript. All authors have read and agreed to the published version of the manuscript.

Funding: This research was funded by Horticulture Innovation Australia Limited through the HN15001 Naturally Nutritious project. 
Acknowledgments: The authors would like to thank Australian Government for the Research Training Program Scholarship and The University of Queensland.

Conflicts of Interest: The authors declare no conflict of interest.

(C) 2020 by the authors. Licensee MDPI, Basel, Switzerland. This article is an open access article distributed under the terms and conditions of the Creative Commons Attribution (CC BY) license (http://creativecommons.org/licenses/by/4.0/). 